\title{
25 Research Soure \\ The Effect of Root Native Tree Species on Soil Shear Strength on Hillslopes of Sierra Madre Oriental, Mexico
}

\section{Rebeca Guadalupe Zavala-González}

Universidad Autonoma de Nuevo Leon Facultad de Ciencias Forestales https://orcid.org/0000-00032216-3217

Israel Cantú-Silva ( $\square$ icantu59@gmail.com )

Facultad de Ciencias Forestales

Humberto González-Rodríguez

Universidad de Los Andes Facultad de Ciencias Forestales y Ambientales

\section{Research}

Keywords: erosion control, tensile strength, root area ratio, shear strength, root cohesion

Posted Date: June 11th, 2020

DOl: https://doi.org/10.21203/rs.3.rs-33721/v1

License: (9) This work is licensed under a Creative Commons Attribution 4.0 International License. Read Full License 


\section{Abstract}

Background: The presence of vegetation reduces soil erosion and shallow slope failure both by reinforcing soil shear resistance and influencing the geo-mechanic conditions of soil. For this reason, vegetation strategies in areas vulnerable to erosion are considered to be an effective control measure for soil erosion.

Method: The tree species used in this research are widespread in the slopes of Chipinque mountain of Sierra Madre Oriental and belong to four native species: Cercis canadensis, Celtis laevigata, Quercus rysophylla and Ligustrum lucidum. In order to investigate the mechanical characteristics of roots, single roots specimens were sampled and tested for tensile strength. The tests were conducted with the Universal Testing Machine Shimadzu type SLFL-100KN to evaluate the influence of root shear strength on the soil using the Wu Model (Wu et al., 1979) as well as to analyze root cohesion and Root Area Ratio (RAR). The latter was calculated by taking both direct (field) and indirect measurements on image processing.

Results: The results show that $C$. laevigata roots have the strongest tensile strenght, followed by $Q$. rysophylla $>$ C. Canadensis $>$ L. lucidum. RAR ranges from C. laevigata $(0.0587 \%)>C$. Canadensis $(0.0585 \%)>$ L. lucidum $(0.0504 \%)>$ Q. rysophylla $(0.0441 \%)$. L. lucidum provides the less increase soil shear strength through root cohesion $\left(16.12 \mathrm{kN} / \mathrm{m}^{2}\right)>C$. canadensis $\left(53.70 \mathrm{kN} / \mathrm{m}^{2}\right)>$ Q. rysophylla $\left(89.07 \mathrm{kN} / \mathrm{m}^{2}\right)$ to C. laevigata $\left(97.41 \mathrm{kN} / \mathrm{m}^{2}\right)$

\section{Background}

Shallow landslides create a significant human and infrastructural hazard with social, economic and environmental consequences. Vegetation takes important part in slope stabilization and erosion control thru soil mechanical effects (Zhang et al. 2008; Comino and Druetta, 2010). Each component in a plant has a function, roots in this case have been considered as an essential technique on slope stabilization and erosion control (Wu et al. 1979), principally due to their mechanical effects (Simon et al. 2006). Roots can improve some mechanics characteristics of soil, such as cohesion and shear strength, which is known as soil fixation (Genet et al. 2006) or root reinforcement (Genet et al. 2008). The presence of roots as a material with strong tension in soil with weak tension provides a composite material with enhanced strength and higher shear strength, a higher soil shear strength result in a higher resistance against erosion and a slope with major stability (Pollen 2007; De Baets et al .2008).

Previous research reported both root density and root tensile strength as the main biotechnical characteristics that control the fixation or reinforcement effect of roots (Gray and Sotir 1996). Root area ratio (RAR) has been used as the main indicator of root distribution and density by many researchers (Abernethy and Rutherfurd 2000; Genet et al. 2008; De Baets et al. 2008). Also, root tensile strength is considered to be an important factor that governs the amount of soil fixation and stabilization (Mattia et al. 2005; Pollen 2007; Genet et al. 2008).Both of the above mentioned parameters are affected by many 
biotic and abiotic factors, such as plant species and age (Gray and Sotir 1996; Nilaweera and Nutalaya 1999; Schmid and Kazda 2001; Genet et al. 2008). Knowledge of mechanical root properties, such as tensile strength, modulus of elasticity and others such as root density, can be used in quantifying the effect of different plants in erosion control measures (Pollen 2007).

Vegetation can be beneficial for stabilizing slopes through mechanical reinforcement (Coppin and Richards 1990; Gray and Sotir 1996; Norris et al. 2008; Mejier et al. 2017). However, the use of plants for engineering actions, provide quantitative information on the influence of root system development on slope stability (Maffra et al. 2019). Most of the mass movement processes that have occurred in Mexico in recent decades have been induced by rain. Thus, according to the above mentioned and as an experimental approach to recognize the influence of root mechanical traits, a research was undertaken to contribute to the understanding of slope stability in forest stands. The study area is located within the Monterrey Metropolitan Area (AMM) belonging to the state of Nuevo Leon, Mexico, and it lays on the edge of the Sierra Madre Oriental Mountain Range (SMO). Site features including geological, geomorphological, and climatic, are responsible for the development of several mass movements (Arrieta et al. 2010).

Slope instability problems in the study area are well known, reason why the continued construction and establishment of houses on this mountain range remains a paradox. In the current study, we aim to further understand the mechanical properties of native species of northeastern Mexico and also quantify their role in increasing soil cohesion that may lead to soil fixation and increased soil resistance against erosion.

\section{Materials And Methods}

\section{Study area}

The study was carried out on the flanks of Chipinque Mountain, located in the northern portion of the Sierra Madre Oriental (Northeast of Mexico, Fig. 1). The climate in the mountain changes drastically depending on the elevation and location. The altitude varies from 750 to 2,200 m.a.s.l., being located between the geographical coordinates $100^{\circ} 18^{\prime}$ and $100^{\circ} 24^{\prime} \mathrm{W}$ and $25^{\circ} 33^{\prime}$ and $25^{\circ} 35^{\prime} \mathrm{N}$. According to the Köppen classification (1936) modified by García (1973), the study area has a climate type of BS1 ( $h$ ') hw (e) ' ' $\mathrm{w}^{\prime}$ ', (semiarid, with marked rains in summer). The average annual temperature is $20.5^{\circ} \mathrm{C}$ and an annual average rainfall of $595 \mathrm{~mm}$, dominating lithosol and rendzine soils (INEGI, 1986).

The vegetation consists of a mixed forest of Pinus and Quercus species, among which are Pinus pseudostrobus (Lindl.), P. teocote (Schiede. Ex Schltdl. \& Cham.) and the Quercus genus: Q. rysophylla (Weath), Q. laeta (Liemb), Q. polymorpha (Schltdl. \& Cham.), Q. laceyi (Small) and Q. canbyi (Trel.) (Alanís et al. 2008).

\section{Sampling and root procedures}


Four native tree species were selected for root characterization and tensile strength test. The root sampling of each plant species, was carried out manually and then 5 individuals per species were randomly selected (Zavala et al. 2019). The roots were extracted from exposed root systems with the purpose of minimum disturbance in the area (Sanchez et al. 2017b) and one complete root system for future procedures. The samples were cut, carefully packed and stored in paper bags. In order to preserve their moisture content, they were stored in a cooler container at the moment of extraction. The root morphological properties were determined in situ prior taking photographs and sampling the roots. Sampling was done at five depths: 0 to $10 \mathrm{~cm}, 10$ to $20 \mathrm{~cm}, 20$ to $30 \mathrm{~cm}, 30$ to $40 \mathrm{~cm}$ and 40 to $50 \mathrm{~cm}$. The collected samples were transferred to the corresponding laboratories at the Facultad de Ciencias Forestales, Universidad Autónoma de Nuevo León. The species selection was made taking into account their native characteristics: natural distribution, abundance and presence in hillside areas. In this way, the species considered were: Cercis Canadensis L. (Fabaceae), Celtis laevigata Willd. (Cannabaceae), Quercus rysophylla Weath. (Fabaceae) and Ligustrum lucidum W.T.Aiton (Oleaceae) (Fig. 2).

Tensile strength test. At the laboratory, the test was well conducted with a total of 120 segments (0.01 to $0.99 \mathrm{~mm}$ ): 30 per species. The methodology used (Sánchez et al 2017) was carried out using a Universal Testing Machine SHIMADZU type SLFL-100Kn. Root samples were clamped and pulled at a constant speed of $10 \mathrm{~mm} / \mathrm{min}$. After each test, the root sample diameter $(\mathrm{mm})$ was measured. Data was visualized using the material testing operation software Trapezium. The applied force $(M)$ required to break the root was taken as a measurement of root breakage to calculate tensile strength $\left(T_{\mathrm{s}}, \mathrm{N} / \mathrm{mm}^{2}\right)$.

$\mathrm{T}_{\mathrm{s}}=\mathrm{F}_{\max } / \pi(\mathrm{D} / 2) 2$

Where: $F_{\max }$ is the maximum force to root breakage $(N)$ and $D$ is the average root diameter $(\mathrm{mm})$ (Mattia et al. 2005, Bischetti et al. 2005, De Baets et al. 2008, Genet et al. 2005).

\section{Root area ratio determination}

On the field, pictures were taken to calculate the root area ratio (RAR), which is defined as the fraction of the soil cross-sectional area occupied by roots per unit area (Gray and Leiser 1982). On the other hand the method of root counting by image analysis described by Vogt and Persson (1991) was used to calculate root area ratio, which consists on the mapping and counting of the exposed roots on a trench from images in order to calculate the cross-sectional area and recreate the root system. This method emulates the traditional profile wall method proposed by Bohm (1979) (Sánchez et al. 2017a). This root trait is a function of depth, so it was taken in the field at five depths 0 to $10 \mathrm{~cm}, 10$ to $20 \mathrm{~cm}, 20$ to $30 \mathrm{~cm}$, 30 to $40 \mathrm{~cm}$ and 40 to $50 \mathrm{~cm}$. This was done by counting the number and thickness of roots in the soil block.

\section{Soil-root cohesion estimation}

The influence of roots on soil (fixation) can be expressed as a cohesion term (O'Loughlin 1974; Wu 1976; Waldron 1977) in the Morh-Coulomb failure criteria were the soil-root composite shear strength $\left(S_{r}\right)$ is 
calculated as follows:

$\mathrm{S}_{\mathrm{r}}=\mathrm{c}^{\prime}+(\sigma-\mathrm{u}) \tan \varphi^{\prime}+\Delta \mathrm{S}$

where $c^{\prime}$ is the effective cohesion of the soil, $\sigma$ is the normal stress due the weight of the water and soil of sliding mass, $u$ is the soil pore-water pressure, $\varphi^{\prime}$ is the effective friction angle of the soil and $\Delta S$ is the apparent cohesion provided by the presence of roots.

The theoretical model developed by Wu (1976), Waldron (1977) and Wu et al. (1979) to estimate the shear strength increase due to presence of roots, assumes that roots are flexible, elastic and perpendicularly oriented to the slip surface when the soil layer is moving. This can be translated into tangential and normal components, specifying how the roots are oriented (normal component) and the magnitude of the force that is provided (tangential component). Assuming that the soil friction angle is not affected (O'Loughlin 1974), the additional cohesion $(\Delta S)$ provided by roots can be calculated as:

$\Delta S=\operatorname{tr}\left(\sin \beta+\cos \beta \tan \varphi^{\prime}\right)$

where $t r$ is the average mobilized tensile strength of roots per unit area of the soil and $\beta$ is the angle of root distortion in the shear zone. Sensitivity analyses show that the values of $\left(\sin \beta+\cos \beta \tan \varphi^{\prime}\right)$ can be approximated as 1.2 for $30^{\circ}<\varphi^{\prime}<40^{\circ}$ and $48^{\circ}<\beta<72^{\circ}$ (Wu et al. 1979; Wu 1995). Thus, the equation can be simplified as:

$\Delta S=1.2 t_{r}$

and tr can be calculated as:

5

where $T_{r i}$ is the tensile strength of an individual root $(i)$ and $\left(A_{r i} \mid A\right)$ is the root area ratio or proportion of root cross sectional area to soil cross sectional area $A$.

\section{Statistical analysis}

Data were analyzed using the Statistical Package for Social Sciences (SPSS) standard version 13.0 for Windows (SPSS Inc., Chicago, IL.). Root tensile strength $\left(T_{S}\right)$ showed supposition of normal distribution and was analyzed using a two-way ANOVA. Since root area ratio (RAR) and root cohesion $\left(\mathrm{C}_{\mathrm{r}}\right)$ data did not show the assumptions of normal distribution, these variables were analyzed using the non-parametric Kruskal-Wallis test (Steel and Torrie 1980). In order to analyze root area ratio (RAR) and root cohesion ( C $_{r}$ ) values for each species for soil depth, the Mann-Whitney U nonparametric test without correction at a $p=$ 0.05 was applied. Power regression models were generated for the correlation species with root tensile strength $(p<0.01)$. 


\section{Results}

A total of 116 samples were successfully tested: 28 for Celtis leavigata, 29 for Quercus rysophylla, 30 for Cercis canadensis and 29 for Ligustrum lucidum. Tension tests were successfully conducted on $85 \%$ of total samples collected. The remaining $15 \%$ failed due to root system damage instead of the applied tension that is attributed to tests discarded by breaking at extremes or by displaced bark.

\section{Root tensile strength}

The ranking of species by average tensile strength is as follows: Celtis leavigata > Quercus rysophylla > Cercis canadensis $>$ Ligustrum lucidum. Considering all tensile strength values obtained, all 4 species analyzed ranged from $156.56 \mathrm{~N} / \mathrm{mm}^{2}$ (Celtis leavigata) to $3.58 \mathrm{~N} / \mathrm{mm}^{2}$ (Ligustrum lucidum).

Results of the two-way ANOVA for root tensile strength do not showed significant differences among species $(p=0.148)$ or for the Sp*Diameter interaction. On the other hand, the Diameter variable showed significant differences $(p=0.001)$ (Table 1$)$.

Table 1

Results of the ANOVA to compare root tensile strength $\left(T_{s}\right)$ within species, root diameter and its interaction.

\begin{tabular}{|llllll|}
\hline Source & SS & df & MS & F-Value & P-Value \\
\hline Species (Sp) & 309,781 & 3 & 103.260 & 2.357 & 0.148 \\
\hline Diameter (D) & $44,239,916$ & 101 & 438.019 & 9.998 & 0.001 ** \\
\hline Sp*D & $1,021,923$ & 7 & 145.989 & 3.332 & 0.057 \\
\hline Error & 350,489 & 8 & 43,811 & & \\
\hline ** indicates a significant difference $(p \leq 0.001)$. & \\
\hline
\end{tabular}

As reported in several studies (Operstein and Frydman 2000; Bischetti et al. 2005; Mattia et al. 2005; Norris 2005; Tosi 2007; Sánchez et al., 2017b) root tensile strength $\left(T_{s}\right)$ decreases with increasing root diameter (D). These $T_{s}-D$ relationships for all species tested in this study are shown in Fig. 3. The parameters and the adjusted- $\mathrm{R}^{2}$ values for the established power regression and the diameter range by which tensile tests were performed are indicated in Table 2 for each species. 
Table 2

Calculated parameters ( $a$ and b values) and adjusted R2 values for the power relationships, expressing the decrease in root tensile strength with increasing root diameter in four native tree species.

\begin{tabular}{|lllllll|}
\hline Plant species & D range $(\mathrm{mm})$ & $\boldsymbol{a}$ & $\boldsymbol{b}$ & $\boldsymbol{n}^{*}$ & Ajusted- $\boldsymbol{R}^{2}$ & Grouping** \\
\hline Cercis canadensis & $1.14-9.70$ & 12.968 & -0.37 & 30 & 0.40 & $\mathrm{~b}$ \\
Celtis laevigata & $1.29-9.90$ & 87.44 & -1.55 & 30 & 0.92 & $\mathrm{a}$ \\
Quercus rysophylla & $1.35-9.28$ & 34.063 & -0.82 & 30 & 0.68 & $\mathrm{~b}$ \\
\hline Ligustrum lucidum & $1.25-9.60$ & 6.9394 & -0.70 & 30 & 0.35 & $\mathrm{C}$ \\
* $\mathrm{n}$ indicates the number of roots tested per species. & & & & \\
**The species were grouped from stronger to weaker roots in tension according to De Baets et al., \\
(2008): a = very good, b = good-regular, c= regular-not good.
\end{tabular}

\section{Root distribution and root area ratio}

The non-parametric ANOVA for root area ratio shows significant differences in the first three soil depths (0-10 cm, 10-20 cm, 20-30 cm; Table 3).

Table 3

P-values from the Kruskal-Wallis test, indicating the significance $(p=0.05)$ of the difference between root cohesion (Cr) and mean RAR values for fibrous root systems and tap root systems.

\begin{tabular}{|lll|}
\hline \multicolumn{3}{|c|}{ Root Parameter Soil Depth (cm) P-value } \\
\hline $\mathrm{C}_{\mathrm{r}}$ & $(0-10)$ & $0.00001^{*}$ \\
\hline $\mathrm{C}_{\mathrm{r}}$ & $(10-20)$ & $0.00032^{\star}$ \\
\hline $\mathrm{C}_{\mathrm{r}}$ & $(20-30)$ & 0.58232 \\
$\mathrm{C}_{\mathrm{r}}$ & $(30-40)$ & 0.08312 \\
$\mathrm{C}_{\mathrm{r}}$ & $(40-50)$ & 0.05539 \\
\hline RAR & $(0-10)$ & $0.0020^{\star}$ \\
\hline RAR & $(10-20)$ & $0.0020^{\star}$ \\
\hline RAR & $(20-30)$ & $0.0020^{*}$ \\
\hline RAR & $(30-40)$ & 0.84271 \\
\hline RAR & $(40-50)$ & 0.07293 \\
\hline (*) indicates a significant difference \\
\hline
\end{tabular}


Cercis canadensis has a typically dense and fibrous root system (Fig. 2c) whereas Ligustrum lucidum, Celtis laevigata and Quercus rysophylla have a typical tap root system with branching (Fig. 2a, b and d). The RAR distribution with depth for the four tree native species is shown in Table 4 where all four species tested have a higher RAR at depth $1(0$ to $10 \mathrm{~cm})$ and show a tendency of higher RAR at lower depths (Fig. 4). Maximum RAR values were observed within $10 \mathrm{~cm}$ of depth for all the species, with a maximum rooting depth of $60 \mathrm{~cm}$.

\section{Root cohesion}

P-value of the non-parametric tests are shown in Table 3. Cohesion values for soil layers (0-10 and 10$20 \mathrm{~cm})$ show significant differences $(p=0.0003)$. By combining root strength with RAR distributions, the potential soil cohesion by roots was estimated using Eq. 4 . Additional root cohesion $\left(\mathrm{C}_{\mathrm{r}}\right)$ provided by the root systems of different native tree species, calculated with Wu's model, is shown in Fig. 5.

The additional cohesion provided by roots $\left(C_{r}\right)$ for the four species analyzed ranged from 16.13 to 73.12 $\mathrm{kN} / \mathrm{m}^{2}$ (Cercis canadensis), from 7.11 to $292.68 \mathrm{kN} / \mathrm{m}^{2}$ (Celtis laevigata), from 12.01 to $197.67 \mathrm{kN} / \mathrm{m}^{2}$ (Quercus rysophylla) and from 9.46 to $28.63 \mathrm{kN} / \mathrm{m}^{2}$ (Ligustrum lucidum). Distribution of average $\mathrm{C}_{\mathrm{r}}$ values is shown in Table 4. 
Table 4

Mean Root area ratio (RAR) at different soil depths in four native tree species.

\begin{tabular}{|c|c|c|c|c|}
\hline Plant species & $n$ & Soil depth (cm) & Mean RAR (\%) & $\begin{array}{l}\text { Mean } C_{r} \\
\left(k N / m^{2}\right)\end{array}$ \\
\hline \multirow[t]{5}{*}{ Cercis canadensis } & \multirow[t]{5}{*}{42} & $0-10$ & 0.06725 & 73.12 \\
\hline & & $10-20$ & 0.06100 & 67.79 \\
\hline & & $20-30$ & 0.05767 & 60.65 \\
\hline & & $30-40$ & 0.05033 & 50.82 \\
\hline & & $40-50$ & 0.03258 & 16.13 \\
\hline \multirow[t]{4}{*}{ Celtis laevigata } & \multirow[t]{4}{*}{36} & $0-10$ & 0.07757 & 292.68 \\
\hline & & $10-20$ & 0.07110 & 67.46 \\
\hline & & $20-30$ & 0.06100 & 22.71 \\
\hline & & $30-40$ & 0.04125 & 7.11 \\
\hline \multirow[t]{4}{*}{ Quercus rysophylla } & \multirow[t]{4}{*}{45} & $0-10$ & 0.07207 & 197.67 \\
\hline & & $10-20$ & 0.06050 & 99.23 \\
\hline & & $20-30$ & 0.04057 & 47.39 \\
\hline & & $30-40$ & 0.02118 & 12.01 \\
\hline \multirow[t]{3}{*}{ Ligustrum lucidum } & \multirow[t]{3}{*}{25} & $0-10$ & 0.06450 & 28.63 \\
\hline & & $10-20$ & 0.05606 & 10.30 \\
\hline & & $20-30$ & 0.04275 & 9.46 \\
\hline
\end{tabular}

\section{Discussion}

\section{Tensile strength}

Generally, tensile strength can be well predicted by root diameter; therefore, mean tensile strength values will be used to predict root contribution to shear strength. The maximum root tensile strength values recorded during testing accounted up to $156 \mathrm{~N} / \mathrm{mm}^{2}$ for Celtis laevigata. These tensile strength values are comparable within the range reported by other authors such as Bischetti et al. (2005), De Baets et al. (2008), Sánchez et al. (2017) for the diameters classes tested for the studied tree species. For all examined species it is noted that root tensile strength decreases with increasing root diameter. Root tensile strength - root diameter relationship varies according to the different plant species. For Cercis 
canadensis, Celtis laevigata and Quercus rysophylla tensile strength within a species varies by root diameter. However, for Ligustrum lucidum, the relationship is relatively poor since the values do not differ markedly from the root diameter classes investigated. This specific behavior for L. lucidum is consistence with that reported by Sánchez (2015), where the behavior is attributed to site characteristics. Likewise, this mechanical root property is controlled by cellulose content: smaller roots have a high cellulose content so their tensile strength is higher (Genet et al. 2005).

\section{Root distribution and Root Area Ratio}

The root distribution over the different depths of soil is highly variable for the species, but some general trends can be observed. As reported by De Baets et al. (2007) and De Baets et al. (2008), for grasses and herbs, the largest proportion of their root biomass consists of roots smaller than $5 \mathrm{~mm}$ in diameter, for shrubs and trees the root distribution over the different root diameter classes is highly variable.

The behavior of root density, generally consists in decreasing with depth. Figure 4 shows an abrupt trend; RAR values are higher in the first layers of soil and dramatically decrease as they reach lower depths. Brundrett (1991) added that roots also vary in growth rates, capacity for secondary growth, lifespans and structural features. It is very important to recognize the different root types because they can have a lot of functions. Higher order lateral roots are generally thinner and do not survive too long comparing to those of lower orders (Preti and Giadrossich 2009; Nyambane and Mwea 2011).

Mechanical characteristics of the root system were assessed by measuring Root Area Ratio (RAR) values and tensile strength of root specimens. RAR (the ratio of the sum of the root areas to the area of soil profile they intersect) values of the roots were obtained in order to estimate root contribution to soil strength. Mean cross-sectional area occupied by roots were obtained for soil depth intervals of $10 \mathrm{~cm}$. All species showed high RAR values between $10-30 \mathrm{~cm}$ soil depth. In general, the vegetation used in this study has shallow roots (maximum root depth $0.65 \mathrm{~m}$ ) and is therefore unable to reinforce the soils to stop the landslides from occurring at $1 \mathrm{~m}$ depths.

Root area ratio declines sharply with depth, because the root samples tested in this study correspond to small diameters far from the trunk, due to test machine limitations (Morgan and Rickson 1995; Abernethy and Rutherfurd 2001; Tosi 2007; Sanchez et al. 2017a). Besides root area ratio, root reinforcement is influenced by the genetic of each species, conditions and soil and slope characteristics (Stokes et al. 2002; Bischetti et al. 2005) which limit the results to a regional area.

As reported by Lee et al. 2020, species with shallow roots and a shorter taproot system are suggested for planting at the toe of the slop (Celtis laevigata and Ligustrum lucidum), while Celtis laevigata and Cercis canadensis with deeper taproots and more profuse lateral root systems are recommended for planting in the middle of the slope.

\section{Soil root-cohesion}


Root cohesion generally decreases with increasing soil depth. Nevertheless, in some cases, it is possible to have an increased root cohesion by increasing soil depth where the root area ratio increases (De Beats et al. 2008). It must be noted that the calculated $C_{r}$ values are relative, since recent studies have shown an overestimation of root cohesions calculated with Wu's model (Operstein and Frydman 2000; Pollen and Simon 2005; De Beat et al. 2008).

Similar to the RAR distribution, root cohesion effect decreases with depth for Celtis laevigata and Quercus rysophylla (Fig. 5), in contrast, the values for Cercis canadensis and Ligustrum lucidum remain relatively unchanged by soil depth. The coefficient of additional soil cohesion provided by roots depends on factors of root material expressed as root area ratio (RAR) at the shear plane, thus comparisons with other studies are not easy since the results typically reported have a big spatial variability but a general trend (Coppin and Richards 1990; Abernethy and Rutherfurd 2001; Sanchez et al. 2017a).

The methodology used in this study suggests the use of root tensile strength of $0.1 \mathrm{~mm}$ to $10 \mathrm{~mm}$ samples (limitations of testing machine). However, these results were used to "extrapolate overestimate" roots of exposed root systems tested where root diameters varied from $0.01 \mathrm{~mm}$ to $25 \mathrm{~mm}$, being the reason for the "overvaluation" of $C_{r}$. Fine roots provide highest tensile strength, however, all roots types have their unique functions and are essential in plant development (Jin et al. 2019).

Roots as well as soil have elastic and plastic properties with different limits of maximum stresses required for breakage due to their genesis and composition. Roots can act as cement as has been suggested (Wu et al. 2001; Jin et al. 2019) improving union strength of soil particles. In this way, this study suggests that soil and roots may behave as a material together with better properties than separately one of the other.

During landslides, roots have a plastic behavior just like soil, behaving together as "a system". The theoretical model developed by Wu (1976), Waldron (1977) and Wu et al. (1979) was used to estimate the shear strength increase due the presence of roots. This model assumes that roots are flexible, elastic and perpendicularly oriented to the slip surface, when the soil layer is moving. However, based on the findings of the present study, we can identify the depth of soil cohesion provided by roots in the range of 0 $30 \mathrm{~cm}$.

\section{Conclusions}

The highest value of root tensile strength was found in Celtis laevigata $\left(156.56 \mathrm{~N} / \mathrm{mm}^{2}\right)$ followed by Quercus rysophylla > Cercis canadensis > Ligustrum lucidum. The highest RAR relationship was found also in Celtis laevigata $(0-10 \mathrm{~cm})$ followed by Quercus rysophylla > Cercis canadensis > Ligustrum lucidum. Highest $\mathrm{C}_{\mathrm{r}}$ was found in Celtis laevigata $\left(287.05 \mathrm{kN} / \mathrm{m}^{2}\right)$ at depth $1(0-10 \mathrm{~cm})$ followed by Quercus rysophylla > Cercis canadensis > Ligustrum lucidum. All species showed the highest RAR and $\mathrm{C}_{r}$ at depth $1(0-10 \mathrm{~cm})$. Due to the overestimation of the Wu's method, which has been mentioned by previous studies, the results shown in present study represent average values for each species. Root area 
ratio was observed as the factor that influences the coefficient of additional cohesion provided by roots on the slope. All species considered for this study contributed to shear strength of slope in a positive way.

Over the last century, the northern portion of the Sierra Madre Oriental Mountain Range, has been affected by a rapidly growing human population that has driven ever-greater usage of slope terrains for road and housing construction. The need to develop effective erosion mitigation and landslide prevention strategies is of utmost importance. This research proposes that roots of native species contribute to soil cohesion at shallow depths and highlights the optimal properties of the root system that are responsible for aiding cohesion. These findings could be useful to stakeholders involved in slope bioengineering projects in regions where landslide can occurs.

\section{Abbreviations}

ANOVA: Analysis of variance; $\mathrm{Cr} / \Delta \mathrm{S}$ : root cohesion; RAR: Root Area Ratio; Ts: Root tensile strength.

\section{Declarations}

\section{Author Contributions}

ZG performed the outdoor study, the data analysis and the writing of the manuscript. CS conceived and designed the experiments. GR contributed to the data analysis and revised the paper. All authors read and contributed to the manuscript revision.

\section{Funding}

This study is supported by a PhD scholarship provided by Conacyt (Consejo Nacional de Ciencia y Tecnología).

\section{Availability of data and materials}

The data obtained and analyzed during the present study are not publicly available (due the data is a part of the author's thesis) but are available from the corresponding author on reasonable request.

\section{Ethics approval and consent to participate}

Not required

\section{Consent for publication}

The authors declare that they give their consent for publication 


\section{Competing interest}

The authors declare that they have no competing interests.

\section{References}

1. Abernethy B, Rutherfurd ID (2000) The effect of riparian tree roots on the mass-stability of riverbanks. Earth Surface Processes and Landforms. The Journal of the British Geomorphological Research Group 25(9): 921-937. https://doi.org/10.1002/1096-9837 (200008)25:9<921: AIDESP93>3.0.CO; 2-7

2. Abernethy B, Rutherfurd ID (2001) The distribution and strength of riparian tree roots in relation to riverbank reinforcement. Hydrological processes 15(1), 63-79. https://doi.org/10.1002/hyp.152

3. Alanís E, Jiménez J, Espinoza D, et al. (2008) Evaluación del estrato arbóreo en un área restaurada post-incendio en el Parque Ecológico Chipinque, México. Revista Chapingo serie ciencias forestales y del ambiente 14(2): 113-118. http://dx.doi.org/10.5154/r.rchscfa.2010.05.032

4. Bischetti G B, Chiaradia EA, Simonato T, et al. (2005) Root strength and root area ratio of forest species in Lombardy (Northern Italy). Plant Soil 278: 11-22. https://doi.org/10.1007/s11104-0050605-4

5. Brundrett MC, Abbott LK (1991) Roots of jarrah forest plants. I. Mycorrhizal associations of shrubs and herbaceous plants. Australian Journal of Botany 39(5): 445-457. https://doi.org/10.1071/BT9910445

6. Bohm W (1979) Methods of Studying Root Systems. Springer- Verlag, Berlin Heidelberg. New York.p188.

7. Comino E, Druetta A (2010) The effect of Poaceae roots on the shear strength of soils in the Italian alpine environment. Soil and Tillage Research 106(2): 194-201.

https://doi.org/10.1016/j.still.2009.11.006

8. Coppin NJ, Richards IG (1990) Use of vegetation in civil engineering London: Construction Industry. Research and Information Association. p 23-36.

9. De Baets S, Poesen J, Knapen A, et al. (2007) Root characteristics of representative Mediterranean plant species and their erosion-reducing potential during concentrated runoff. Plant Soil 294:169183. https://doi.org/10.1007/s11104-007-9244-2

10. De Baets S D, Torri D, Poesen J, et al. (2008) Modelling increased soil cohesion due to roots with EUROSEM. Earth Surface Processes and Landforms. The Journal of the British Geomorphological Research Group, 33(13): 1948-1963. https://doi.org/10.1002/esp.1647

11. García E (1981) Modificaciones al Sistema de Clasificación Climática de Köppen para adaptarlo a las condiciones de la República Mexicana. ISBN: 970-32-1010-4.

12. Genet M, Stokes A, Salin F, et al. (2005) The influence of cellulose content on tensile strength in tree roots. Plant and soil, 278(1-2): 1-9. https://doi.org/10.1007/s11104-005-8768-6 
13. Genet, M., Stokes, A., Fourcaud, et al. (2006) Soil fixation by tree roots: changes in root reinforcement parameters with age in Cryptomeria japonica D. Don. Plantations. Disaster mitigation of debris flows, slope failures and landslides 535- 542

14. Genet M, Kokutse N, Stokes A, et al. (2008) Root reinforcement in plantations of Cryptomeria japonica D. Don: effect of tree age and stand structure on slope stability. Forest ecology and Management 256(8): 1517-1526. https://doi.org/10.1016/j.foreco.2008.05.050

15. Gray D H, Leiser AT (1982) Biotechnical slope protection and erosion control. Van Nostrand Reinhold Company Inc, New York.

16. Gray DH, Sotir RB (1996) Biotechnical and Soil Bioengineering Slope Stabilization: A practical Guide for Erosion Control. New York: John Wiley and Sons.p.30-45.

17. Instituto Nacional de Estadística Geografía e Informática. INEGI (1986) Síntesis Geográfica de Nuevo León. Secretaría de Programación y Presupuesto. México, D.F. 170.

18. Jin, H. F., Shi, D. M., Zeng, X. Y., et al. (2019) Mechanisms of root-soil reinforcement in bioembankments of sloping farmland in the purple hilly area, China. Journal of Mountain Science, 16(10):2285-2298. https://doi.org/10.1007/s11629-019-5476-x

19. Lee, J. T., Chu, M. Y., Lin, Y. S.,et al. (2020). Root Traits and Biomechanical Properties of Three Tropical Pioneer Tree Species for Forest Restoration in Landslide Areas. Forests, 11(2), 179. https://doi:10.3390/f11020179

20. Maffra C, Sousa R, Sutili F and Pinheiro R (2019) The Effect of Roots on the Shear Strength of Texturally Distinct Soils. Floresta e Ambiente, 26(3):3-5. https://doi.org/10.1590/2179-8087.101817

21. Meijer G J, Bengough A G, Knappett J A, et al. (2017) In situ root identification through blade penetrometer testing-part 2: field testing. Géotechnique, 68(4): 320-331. https://doi.org/10.1680/jgeot.16.p.204

22. Mattia C, Bischetti G B and Gentile F (2005) Biotechnical characteristics of root systems of typical Mediterranean species. Plant and soil, 278(1-2):23-32. https://doi.org/10.1007/s11104-005-7930-5

23. Montalvo J, Chávez G, Velasco F, Navarro I (2010) Causes and effects of landslides in the Monterrey Metropolitan area, NE Mexico. Nova Science Publishers, Inc. In: Landslides: Causes, Types and Effects. 17-18.

24. Morgan R P C, Rickson R J (1995) Water Erosion Control. In slope stabilization and erosion control: a bioengineering approach, Morgan, R. P. C. and R. J Rickson. (eds), E and FN Spon, London.p.133190. https://doi.org/10.4324/9780203362136

25. Nilaweera N S, Nutalaya $P$ (1999) Role of tree roots in slope stabilization. Bulletin of engineering geology and the environment, 57(4): 337-342. https://doi.org/10.1007/s100640050056

26. Norris JE (2005) Root reinforcement by hawthorn and oak roots on a highway cut-slope in Southern England. Plant Soil 278: 43-53. https://doi.org/10.1007/s11104-005-1301-0

27. Norris J E, Stokes A, Mickovski S B, et al. (2008) Slope stability and erosion control: Ecotechnological Solutions VI, Hardcover, ISBN: 978-1-4020-6675-7, 290. https://doi.org/10.1007/978-1-4020-6676-4 
28. Nyambane O S and Mwea S K (2011) Root tensile strength of 3 typical plant species and their contribution to soil shear strength; a case study: Sasumua Backslope, Nyandarua District, Kenya. Journal of Civil Engineering Research and Practice, 8(1): 57-73. https://doi.org/10.4314/jcerp.v8i1.69525

29. O'loughlin C L (1974) The effect of timber removal on the stability of forest soils. Journal of Hydrology, 13(2): 121-134.

30. Operstein V, Frydman S (2000) The influence of vegetation on soil strength. Ground Improv 4: 81-89.

31. Pollen N (2007) Temporal and spatial variability in root reinforcement of streambanks: accounting for soil shear strength and moisture. Catena, 69(3): 197-205.

https://doi.org/10.1016/j.catena.2006.05.004

32. Pollen $\mathrm{N}$ and Simon A (2005) Estimating the mechanical effects of riparian vegetation on stream bank stability using a fiber bundle model. Water Resour Res 41: 1-11. https://doi.org/10.1029/2004wr003801

33. Preti F, Giadrossich F (2009) Root reinforcement and slope bioengineering stabilization by Spanish Broom (Spartium junceum L.). Hydrology and Earth System Sciences, 13(9): 1713-1726. https://doi.org/10.5194/hess-13-1713-2009

34. Sánchez $L$ (2015) An integrated study of sediment related disaster prevent and erosion control for urbanized forest slopes in Nuevo León, México. PhD Thesis, Fac. of Bioresource and Bioenvironmental Sciences, Kyoto Univesity, 1-7, 36-39.

35. Sánchez L, Tetsuya K, Hasnawir, Cantú I (2017a) Influence of root reinforcement of forest species on the slope stability of Sierra Madre Oriental, Mexico. J. Fac. Agr., Kyushu University, 62(1): 177-181.

36. Sánchez L, Tetsuya K, Cantú I, Yáñez I, Hasnawir, Pequeño M. (2017b) Comparisons of the root mechanical properties of three native Mexican tree species for soil bioengineering practices. Botanical Sciences 95(2): 1-11. https://doi.org/10.17129/botsci.802

37. Schmid I, and Kazda M (2001) Vertical distribution and radial growth of coarse roots in pure and mixed stands of Fagus sylvatica and Picea abies. Canadian Journal of Forest Research, 31(3): 539548. https://doi.org/10.1139/cjfr-31-3-539

38. Secretaria de desarrollo sustentable del estado de Nuevo León (2013) Atlas de riesgos para el estado de Nuevo León, 1: 8-22. https://doi.org/10.1515/9783110226201.333

39. Simon A, Pollen N, Langendoen E (2006) Influence of two woody riparian species on critical conditions for streambank stability: Upper Truckee River, California 1. Jawra Journal of the American Water Resources Association, 42(1):99-113. https://doi.org/10.1111/j.1752-1688.2006.tb03826.x

40. Stokes A, Fourcaud T, Hruska J, (2002) An evaluation of different methods to investigate root system architecture of urban trees in situ: I. Ground-penetrating radar. Journal of Arboriculture, 28(1): 2-10.

41. Tosi M (2007) Root tensile strength relationships and their slope stability implications of three shrub species in Northern Apennines (Italy). Geomorphology 87:268-283. https://doi.org/10.1016/j.geomorph.2006.09.019 
42. Vogt K A, Persson H (1991) Measuring growth and development of roots. Techniques and approaches in forest tree ecophysiology, 477-501.

43. Waldron L J (1977) The shear resistance of root-permeated homogeneous and stratified soil. Soil Science Society of America Journal, 41(5):843-849. https://doi.org/10.2136/sssaj1977.03615995004100050005x

44. Wu TH (1976) Investigation of landslides on Prince of Wales Island, Alaska. Ohio State University Department of Civil Engineering, Geotechnical Engineering Report 5-93.

45. Wu T H, McKinnell WP, Swanston DN (1979) Strength of tree roots and landslides on Prince of Wales Island. Canadian Geotechnical Journal 16: 19-33. https://doi.org/10.1139/t79-003

46. Wu T H (1995) Slope stabilization. In: Morgan RPC, Rickson RJ .Slope stabilization and erosion control, a bioengineering approach. E and FN Spon, London, 221-264. https://doi.org/10.4324/9780203362136

47. Wu Y, Liu Q, Qiao YK, et al. (2001) Species diversity changes in subalpine coniferous forests of different restoration stages and their effects on soil properties. Acta Phytoecologica Sinica 25(6):648-655.

48. Zhang C, Chen L, Jiang J, and Zhou, S (2012) Effects of gauge length and strain rate on the tensile strength of tree roots. Trees, 26(5): 1577-1584. https://doi.org/10.1007/s00468-012-0732-5

49. Zavala R, Cantú I, Sánchez L, González H, Tetsuya K (2019) Ten Native Tree Species for potential use in Soil Bioengineering in northeastern Mexico. Botanical Sciences, 97(3), 291-300.

\section{Figures}

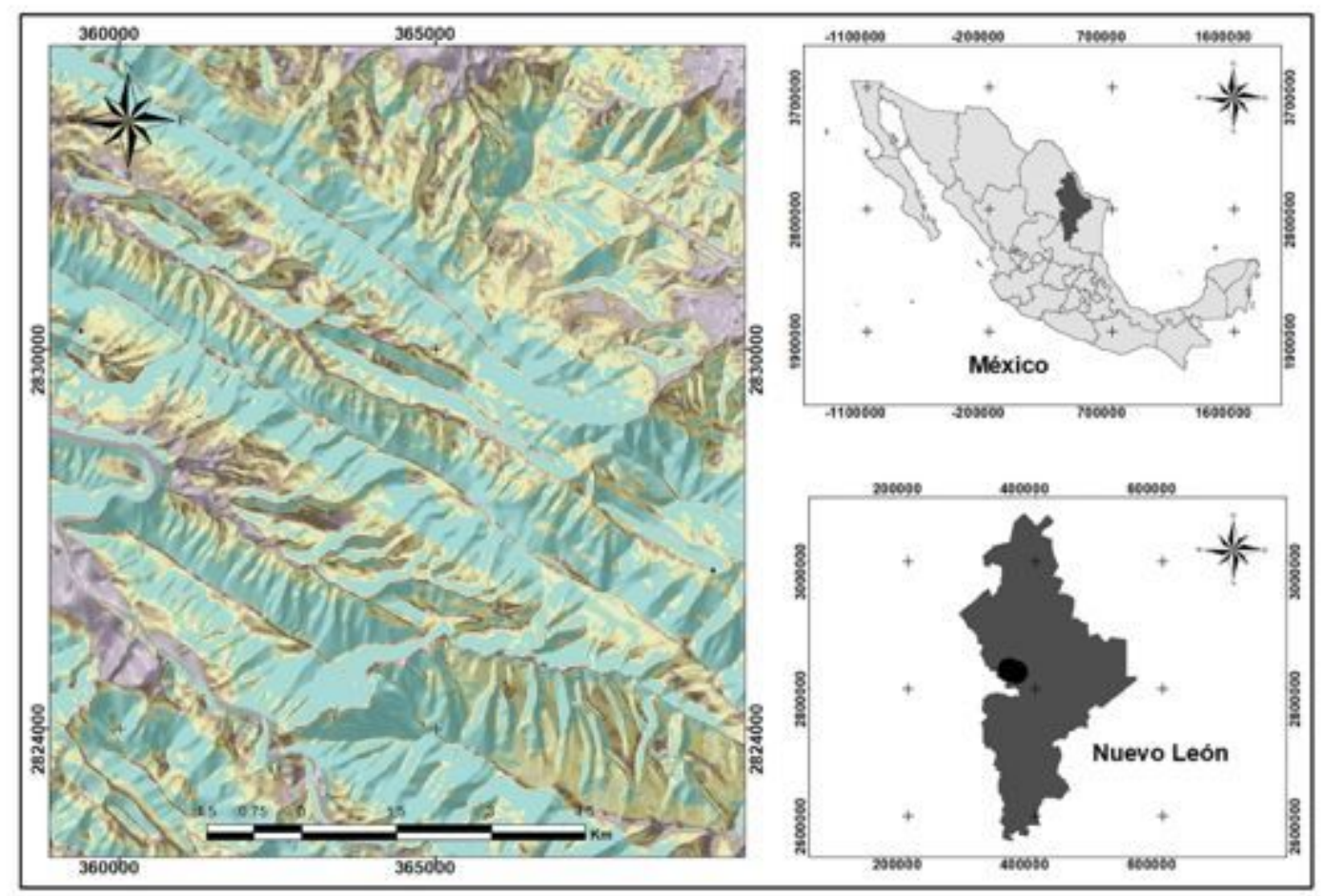


Figure 1

Study area. The image show the location of the flanks of Chipinque Mountain in Nuevo León, Mexico

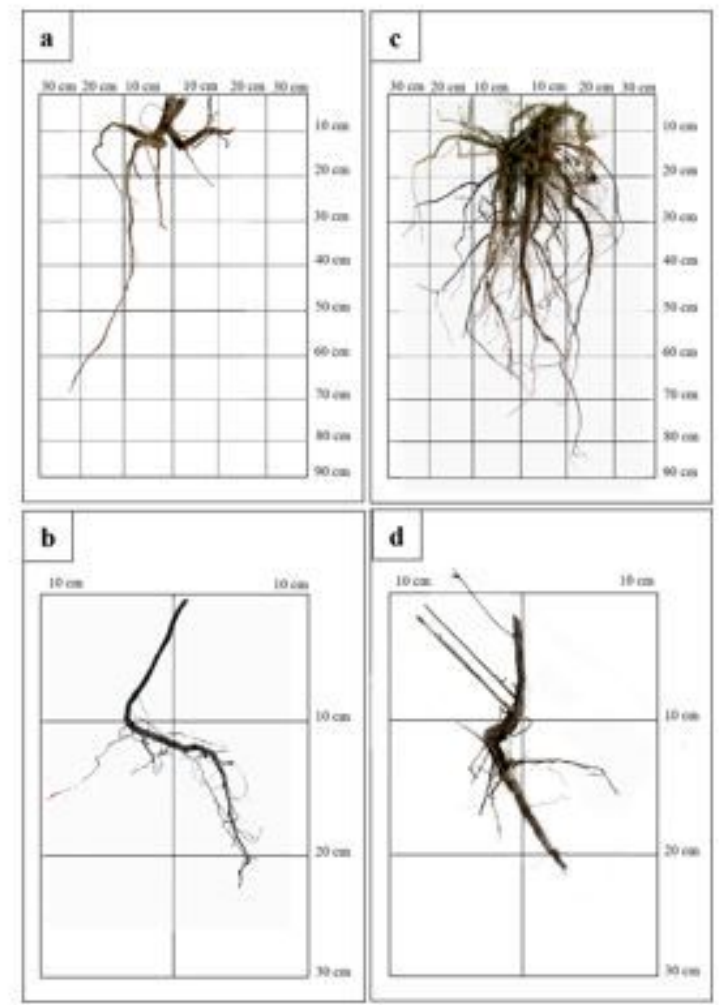

\section{Figure 2}

Examples of extracted roots sampled at the study area: a) Celtis laevigata, b) Quercus rysophylla, c) Cercis canadensis, d) Ligustrum lucidum. 


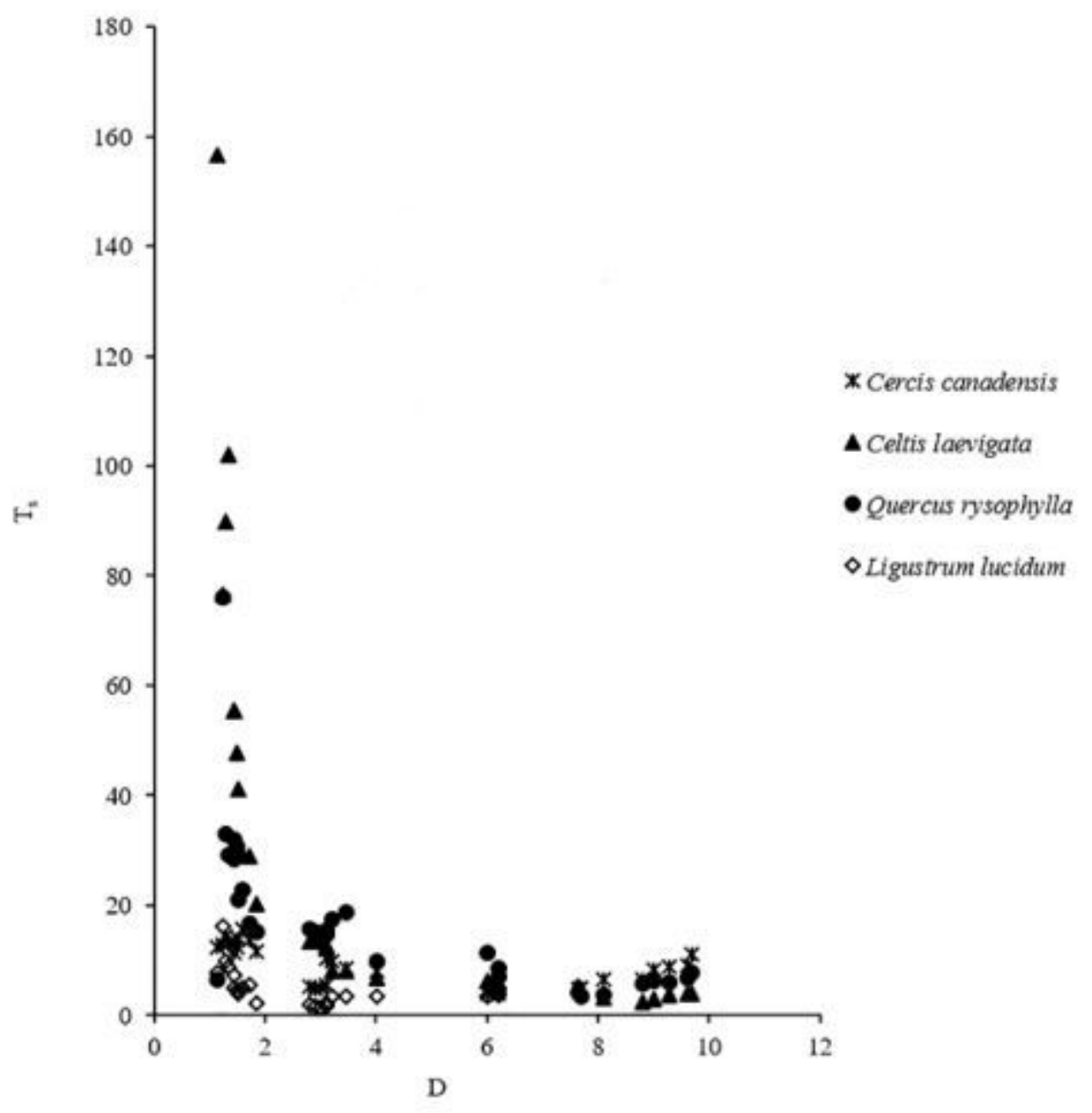

Figure 3

Relationship between root tensile strength $(T s, \mathrm{~N} / \mathrm{mm} 2)$ and root diameter $(\mathrm{D}, \mathrm{mm})$ for roots of four native species. Ts represents the predicted root tensile strength values according to the relationships listed in Table 2. 


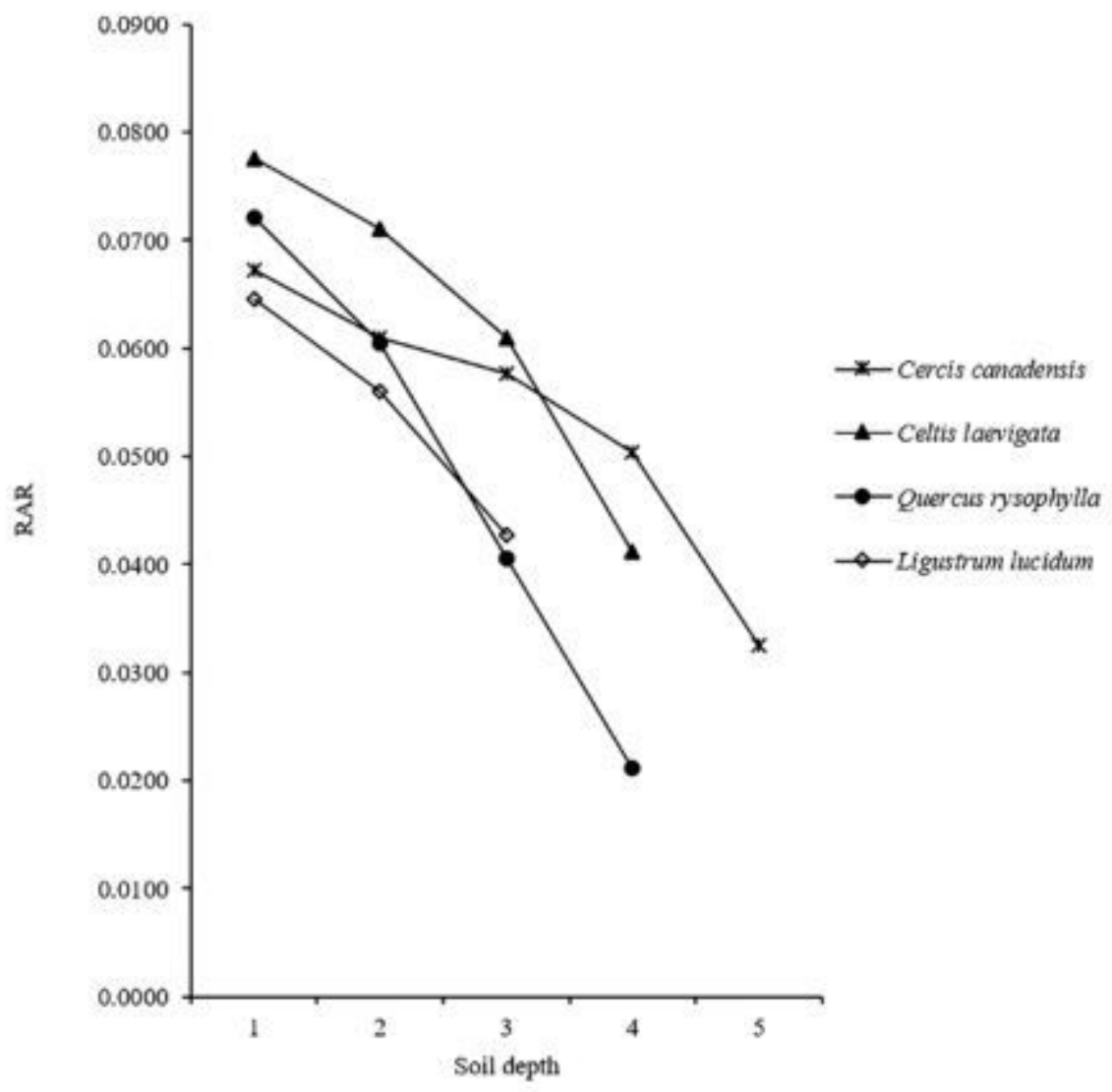

\section{Figure 4}

Relationship between root area ratio (RAR, \%) distribution with soil depth profile $(1=0-10 \mathrm{~cm} ; 2=10-20 \mathrm{~cm}$; $3=20-30 \mathrm{~cm} ; 4=30-40 \mathrm{~cm} ; 4=40-50 \mathrm{~cm}$ ) in four native tree species. 


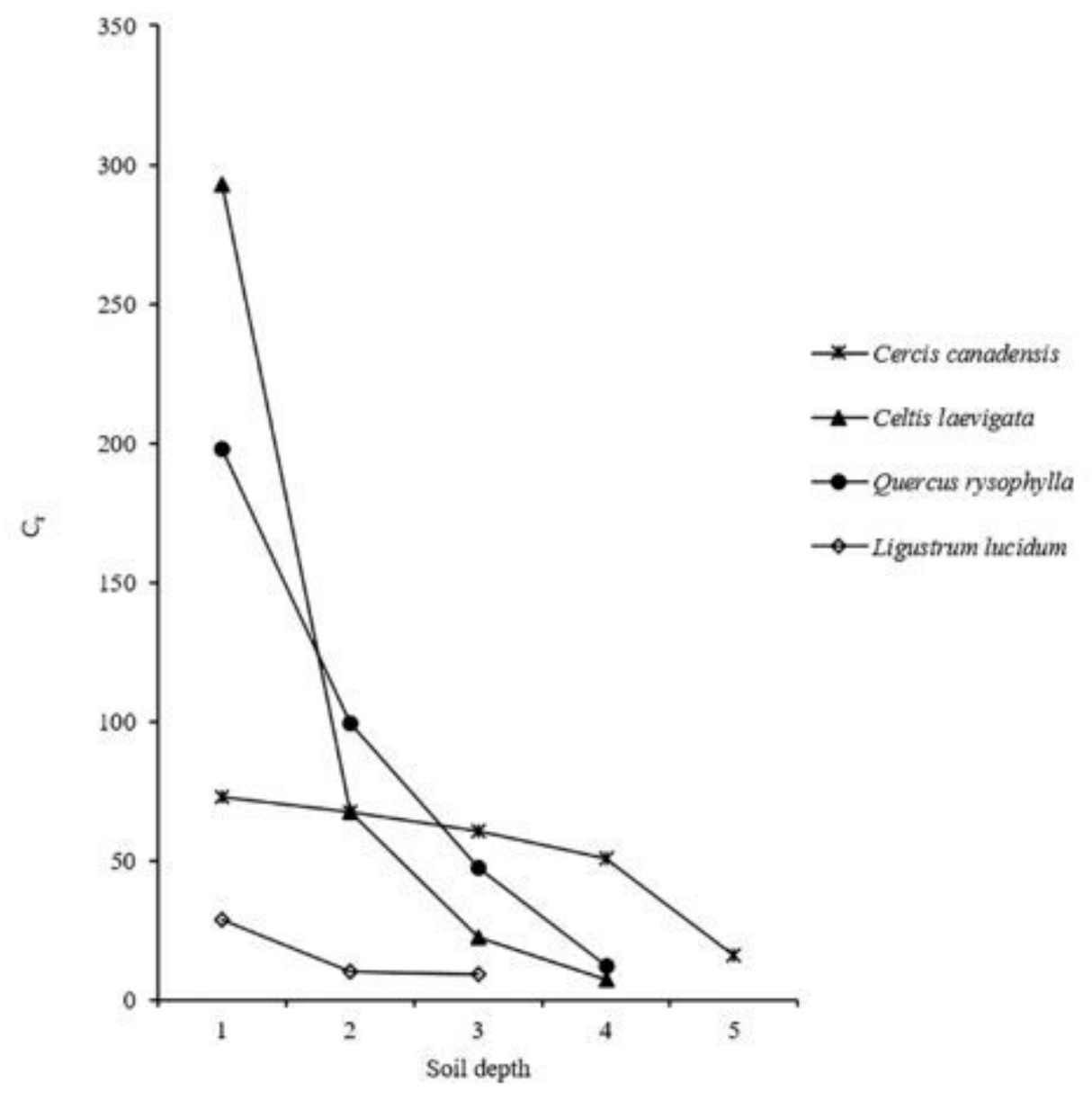

Figure 5

Relationship between soil root-cohesion $(\mathrm{Cr}, \mathrm{kN} / \mathrm{m} 2)$ distribution with soil depth profile $(1=0-10 \mathrm{~cm} ; 2=10$ $20 \mathrm{~cm} ; 3=20-30 \mathrm{~cm} ; 4=30-40 \mathrm{~cm} ; 4=40-50 \mathrm{~cm}$ ) for four native tree species. 